\title{
Nutrient management for jute-rice cropping system using soil test target yield equation
}

\author{
M.V. Singh ${ }^{1}$, Mukesh Kumar*, S Mitra and M. Ramesh Naik \\ Central Research Institute for Jute and Allied Fibres, Barrackpore, Kolkata -700120 (WB), INDIA \\ ${ }^{1}$ Crop Research Station, Bahraich -271801 (U.P.), INDIA \\ *Corresponding author. E-mail: mukesh.agro@gmail.com
}

Received: November 14, 2014; Revised received: February 25, 2015; Accepted: April 4, 2015

\begin{abstract}
A field experiment was conducted during the year 2011-13 to study the nutrient management based on soil test to achieve the target yield of jute and rice and their effect of soil nutrient status for jute-rice cropping system. The target yield of jute fibre (3.5 t/ha) with $-6 \%$ deviation and target yield of rice (5.5 t/ha) were achieved with application of $100 \%$ NPK based on ST-TY based along with 5 t/ha Farm Yard Manure (FYM). The highest system productivity (11.7 t/ha) and benefit-cost ratio (3.16) was also recorded higher with application $100 \%$ NPK based on ST-TY based along with $5 \mathrm{t} / \mathrm{ha}$ FYM. The nutrient uptake by crops and soil nutrients status were higher after three year of jute-rice cropping sequence when NPK were applied with FYM. Hence, combination of inorganic and organic (FYM) fertilizer could achieve target yield and maintain the soil fertility status.
\end{abstract}

Keyword: Economics, Jute, Nutrient management, Nutrient uptake, Rice, STCR, Yield

\section{INTRODUCTION}

Balanced fertilizer application in a cropping system is pre-requisite for sustainable production system as well as appropriate soil nutrient resilience. With the development of high yielding and fertilizer responsive varieties of almost all crops escalated the indiscriminate use of fertilizers thus increases cost of cultivation and environment pollution. Hence, need based estimation of $\mathrm{N}, \mathrm{P}$ and $\mathrm{K}$ correlating their requirement with specific target yield depending on their native soil status may fit to balanced application of NPK fertilizers. The 'target yield equation' (TYE) is considered as a soil and fertilizer based precision farming strategy to meet nutrient demands for a specified yield (Balasubramanian et al., 1999). However, application of N,P and K fertilizer on soil test target yield (ST-TY) based may meet the productivity but it has negative impact on soil health, hence, integrated nutrient management i.e. combination of inorganic and organic in jute-rice cropping system help to enhance the jute and rice productivity while maintaining the soil health (Ghosh, 2008). Keeping this view in mind the experiment was conducted to achieve the target yield of jute and rice and their effect of soil nutrient status for jute-rice cropping system

\section{MATERIALS AND METHODS}

The experiment was conducted at Crop Research Station, Bahraichin jute-rice system during 2011-13. The soil of experimental field was sandy loam with $\mathrm{pH} 7.5$, organic carbon $0.24 \%$ and available N, P and K 215, 22.5 and $125 \mathrm{~kg} /$ ha,respectively. Doses of $\mathrm{N}, \mathrm{P}_{2} \mathrm{O}_{5}$ and $\mathrm{K}_{2}$ Ocalculatedon soil test basis by using following equations:

For jute (Singh et al., 2012)

$\mathrm{FN}=8.03 \mathrm{~T}-0.45 \mathrm{SN}$

$\mathrm{FP}=1.49 \mathrm{~T}-0.27 \mathrm{SP}$

$\mathrm{FK}=2.77 \mathrm{~T}-0.19 \mathrm{SK}$

For rice (Ray et al., 2000 )

$\mathrm{FN}=5.29 \mathrm{~T}-0.39 \mathrm{SN}$

$\mathrm{FP}=1.03 \mathrm{~T}-0.24 \mathrm{SP}$

$\mathrm{FK}=1.98 \mathrm{~T}-0.20 \mathrm{SK}$

Where, T= Yield target; FN, FP and FK is fertilizer N, $\mathrm{P}_{2} \mathrm{O}_{5}$ and $\mathrm{K}_{2} \mathrm{O}(\mathrm{kg} / \mathrm{ha})$, respectively;

SN,SP and SK are available N P and K of soil $(\mathrm{kg} /$ ha),respectively.

Seven nutrient management practices viz. $\mathrm{T}_{1}$ - Control, $\mathrm{T}_{2}$ - Recommended dose of jute fertilizer (RDF) i.e. for jute $60 \mathrm{~kg} \mathrm{~N}, 30 \mathrm{~kg} \mathrm{P}_{2} \mathrm{O}_{5}$ and $30 \mathrm{~kg} \mathrm{~K} \mathrm{~K}_{2} \mathrm{O} / \mathrm{ha}$ and for rice $150 \mathrm{~kg} \mathrm{~N}, 60 \mathrm{~kg} \mathrm{P}_{2} \mathrm{O}_{5}$ and $60 \mathrm{kgK}_{2} \mathrm{O} / \mathrm{ha}, \mathrm{T}_{3}$ - RDF + Farm yard manure (FYM), $\mathrm{T}_{4}-100 \% \mathrm{NPK}$ on ST-TY (Target for Jute $-3.5 \mathrm{t} / \mathrm{ha}$ and for rice- $5.5 \mathrm{t} /$ ha), $\mathrm{T}_{5}-100 \%$ NPK on ST-TY (Target for jute $-4.0 \mathrm{t} / \mathrm{ha}$ and for rice $6.5 \mathrm{t} / \mathrm{ha}), \mathrm{T}_{6}-\mathrm{T}_{4}+5 \mathrm{t} / \mathrm{ha}$ of FYM and $\mathrm{T}_{7}$ $-\mathrm{T}_{5}+5 \mathrm{t} / \mathrm{ha}$ FYM were tested in randomized block design with three replications for jute and rice. Jute variety 'JRC-212' was sown in the first week of April and rice variety 'NDR 62 ' was transplanted in $2^{\text {nd }}$ week of July in every year with recommended package and practices. The fibre yield in jute crop and grain yield of rice crop was recorded after harvesting of crop. Soil and plant samples were collected at harvest were 
dried, processed and analyzed for available $\mathrm{N}$ by alkaline permanganate method, available P by Olsen's method and available $\mathrm{K}$ by flame photometer following standard procedures (Jackson, 1973). The economics in term of benefit cost ratio was also calculated at price prevailing in nearest market.The fibre yield of jute, grain yield of rice, and other parameters of nutrient dynamics were subjected to standard analysis of variance (ANOVA) and treatment differences were tested following tests of least significant difference (LSD) at statistical significance level of $\mathrm{P} \leq 0.05$ (Gomez and Gomez, 1984).

\section{RESULTS AND DISCUSSION}

Fibre yield, rice yield and system productivity: The target yield of jute $(3.5 \mathrm{t} / \mathrm{ha})$ was achieved with $-6 \%$ deviation (Table 1) with application of $100 \% \mathrm{NPK}$ based on Soil Test Target Yield (ST-TY) equation along with $5 \mathrm{t} / \mathrm{ha}$ of FYM $\left(\mathrm{T}_{6}\right)$. The $100 \%$ NPK application on ST-TY achieved only $84.5 \%$ of target jute fibre yield. The higher jute fibre target yield ( $4.0 \mathrm{t} /$ ha) could not achieved by any treatments. The target yield of rice $(5.5 \mathrm{t} / \mathrm{ha})$ was also achieved with $\mathrm{T}_{6}$. The higher target yield $(6.5 \mathrm{t} / \mathrm{ha})$ of rice could not achieved by any treatments, however, 100\% NPK based on ST-TY along with $5 \mathrm{t}$ /ha of FYM was achieved $89.5 \%$ of this target yield. The integration of inorganic with organic (FYM) was ensured the achievement of target yield of jute and rice and only inorganic $(\mathrm{N}, \mathrm{P}$ and $\mathrm{K})$ did not achieve the target yield in both jute and rice. Balanced nutrition to soil, through integration of both organic and chemical nutrient sources appears to be essential. It provides adequate nutrients to crop uptake which promotes jute and rice growth and subsequent development of yield attributes lead to higher yield (Ghosh, 2008;Guha,et al., 2008).Target yield was not achieved exactly, showing a slight deviation from the grain yield was might be due to unavailability of the full amount of applied nutrients to the plant as estimated to achieve the targeted yield. One possibility is that release of nutrients from applied fertilizer occurs spontaneously; however, subsequent uptake by plant is not taking place concurrently. Thus, entire amount of applied fertilizers could not have been up took due to lack of synchronization of its release with its absorption by plant, accounting for uncontrollable losses (Balasubramanian et al., 2003).The system productivity and benefit cost ratio was significantly $(\mathrm{P} \leq$ 0.05 ) higher in $T_{6}$ and $T_{7}$, where FYM was integrated

Table 1. Jute fibre yield, rice yield, percent achievement of target yield, system productivity and benefit-cost ratio under juterice cropping system (pooled data of 2011 to 2013).

\begin{tabular}{|c|c|c|c|c|c|c|}
\hline Treatments & $\begin{array}{l}\text { Fibre yield } \\
\quad(t / h a)\end{array}$ & $\begin{array}{l}\text { \% achieve- } \\
\text { ment of jute } \\
\text { fibre target } \\
\text { yield }\end{array}$ & $\begin{array}{l}\text { Rice } \\
\text { yield }\end{array}$ & $\begin{array}{l}\% \text { achieve- } \\
\text { ment of rice } \\
\text { target yield }\end{array}$ & $\begin{array}{c}\text { System } \\
\text { produc- } \\
\text { tivity } \\
\text { (t/ha) }\end{array}$ & B:C \\
\hline $\begin{array}{l}\mathrm{T}_{1} \text { : Control ( without any } \\
\text { fertilizer } / \mathrm{FYM} \text { ) }\end{array}$ & 1.25 & $35.7 / 31.5 \#$ & 1.56 & 28.4/24.0\# & 3.77 & 1.26 \\
\hline $\begin{array}{l}\mathrm{T}_{2} \text { : Recommended dose of } \\
\text { fertilizer (RDF) (60:30:30 kg } \\
\text { NPK) }\end{array}$ & 2.47 & 70.6/61.7\# & 4.25 & 77.3/65.4\# & 8.62 & 2.58 \\
\hline $\begin{array}{l}\mathrm{T}_{3}: \mathrm{RDF} \text { +organic manure } \\
\text { (equivalent to } 5 \mathrm{t} / \mathrm{ha} \text { of } \\
\mathrm{FYM} \text { ) }\end{array}$ & 2.79 & 79.7/69.7\# & 4.67 & 84.9/71.2\# & 9.61 & 2.81 \\
\hline $\begin{array}{l}\mathrm{T}_{4}: 100 \% \text { NPK on ST-TY } \\
\text { ( Target : Jute }-3.5 \mathrm{t} / \mathrm{ha} \text {, rice } \\
5.5 \mathrm{t} / \mathrm{ha} \text { ) }\end{array}$ & 2.95 & 84.3 & 5.02 & 91.3 & 10.24 & 2.97 \\
\hline $\begin{array}{l}\mathrm{T}_{5}: 100 \% \text { NPK on ST-TY } \\
\text { ( Target : Jute }-4.0 \mathrm{t} / \mathrm{ha} \text {, rice } \\
6.5 \mathrm{t} / \mathrm{ha} \text { ) }\end{array}$ & 3.10 & 88.6 & 5.53 & 85 & 11.01 & 2.98 \\
\hline $\begin{array}{l}\mathrm{T}_{6}: \mathrm{T}_{4}+\text { organic manure } \\
\text { (equivalent to } 5 \mathrm{t} / \mathrm{ha} \text { of } \\
\text { FYM) }\end{array}$ & 3.30 & 94.3 & 5.64 & 100.2 & 11.48 & 3.16 \\
\hline $\begin{array}{l}\mathrm{T}_{7}: \mathrm{T}_{5}+\text { organic manure } \\
\text { (equivalent to } 5 \mathrm{t} / \mathrm{ha} \text { of } \\
\text { FYM) }\end{array}$ & 3.30 & 94.3 & 5.82 & 89.5 & 11.66 & 3.12 \\
\hline $\operatorname{SEm} \pm$ & 0.04 & & 0.03 & & 0.30 & 0.06 \\
\hline $\operatorname{LSD}(\mathrm{P}=0.05)$ & 0.08 & & 0.09 & & 1.0 & 0.18 \\
\hline
\end{tabular}

\# Achievable yield of higher target i.e. Jute $-4.0 \mathrm{t} / \mathrm{ha}$ and rice $6.5 \mathrm{t} / \mathrm{ha}$ 
Table 2. Nutrient uptake and available nutrients status in soil after three year of cropping system.

\begin{tabular}{|c|c|c|c|c|c|c|c|c|c|}
\hline \multirow[t]{2}{*}{ Treatments } & \multicolumn{3}{|c|}{$\begin{array}{l}\text { Nutrient uptake by } \\
\text { jute crop (kg/ha) }\end{array}$} & \multicolumn{3}{|c|}{$\begin{array}{l}\text { Nutrient uptake by } \\
\text { rice crop }(\mathrm{kg} / \mathrm{ha})\end{array}$} & \multicolumn{3}{|c|}{$\begin{array}{l}\text { Available nutrient Status } \\
\text { after three year of cropping } \\
(\mathrm{kg} / \mathrm{ha})\end{array}$} \\
\hline & $\mathbf{N}$ & $\mathbf{P}$ & $\mathbf{K}$ & $\mathbf{N}$ & $\mathbf{P}$ & $\mathbf{K}$ & $\mathbf{N}$ & $\mathbf{P}$ & $\mathbf{K}$ \\
\hline Initial soil status & & & & & & & 225.0 & 22.5 & 125.0 \\
\hline $\begin{array}{l}\mathrm{T}_{1} \text { : Control ( without any } \\
\text { fertilizer /FYM) }\end{array}$ & 32.6 & 14.1 & 39.2 & 31.92 & 15.9 & 23.3 & 114.3 & 19.5 & 110.7 \\
\hline $\begin{array}{l}\mathrm{T}_{2}: \text { Recommended dose of } \\
\text { fertilizer(RDF)(60:30:30 } \\
\left.\text { NPK ha }^{-1}\right)\end{array}$ & 69.6 & 28.4 & 78.7 & 86.35 & 43.05 & 63.15 & 197.0 & 21.8 & 115.7 \\
\hline $\mathrm{T}_{3}: \mathrm{RDF}+5 \mathrm{t} / \mathrm{ha} \mathrm{FYM}$ & 80.7 & 32.8 & 91.6 & 92.95 & 46.9 & 70.1 & 202.7 & 22.6 & 117.7 \\
\hline $\begin{array}{l}\mathrm{T}_{4}: 100 \% \text { NPK on ST-TY } \\
\text { (Target : Jute }-3.5 \mathrm{t} / \text { ha, rice } \\
5.5 \mathrm{t} / \text { ha })\end{array}$ & 84.9 & 34.8 & 64.6 & 100.0 & 50.77 & 74.55 & 208.7 & 23.8 & 121.0 \\
\hline $\begin{array}{l}\mathrm{T}_{5}: 100 \% \mathrm{NPK} \text { on ST-TY } \\
\text { (Target : Jute }-4.0 \mathrm{t} / \mathrm{ha} \text {, rice } \\
6.5 \mathrm{t} / \mathrm{ha})\end{array}$ & 87.1 & 36.6 & 96.8 & 108.15 & 57.12 & 83.7 & 216.0 & 23.9 & 122.7 \\
\hline $\mathrm{T}_{6}: \mathrm{T}_{4}+5 \mathrm{t} / \mathrm{ha}$ of FYM & 88.8 & 37.1 & 101.5 & 112.9 & 67.5 & 87.05 & 231.0 & 24.8 & 128.7 \\
\hline $\mathrm{T}_{7}: \mathrm{T}_{5}+5 \mathrm{t} / \mathrm{ha} \mathrm{FYM}$ & 94.9 & 37.7 & 105.5 & 117.35 & 63.82 & 91.1 & 246.0 & 25.4 & 128.7 \\
\hline $\mathrm{SE} \mathrm{m} \pm$ & 0.36 & 0.22 & 0.90 & 0.66 & 0.33 & 0.39 & 0.61 & 0.15 & 0.50 \\
\hline $\operatorname{LSD}(\mathrm{P}=0.05)$ & 1.1 & 0.7 & 2.8 & 1.98 & 1.00 & 1.18 & 1.87 & 0.46 & 1.5 \\
\hline
\end{tabular}

with ST-TY based application of NPK compared to $\mathrm{T}_{1}$, $\mathrm{T}_{2}$ and $\mathrm{T}_{3}$ treatments (Table 1). The combination of inorganic and organic resulted in higher productivity of jute/mesta and rice was also reported by Ray, et al. (2000) in jute-rice -wheat cropping system, Saha, et al. (2008) in roselle; Kumar, et al. (2010) in jute and Singh,et al. (2011) in mesta-rice cropping system.

Nutrients uptake and its status in soil: The higher nutrient uptake (94.9 N, 37.7 $\mathrm{P}$ and $105.5 \mathrm{~K} \mathrm{~kg} / \mathrm{ha}$ ) by jute and $(117.3 \mathrm{~N}, 68.8 \mathrm{P}$ and $91.1 \mathrm{~K} \mathrm{~kg} / \mathrm{ha}$ by rice crop were recorded under $\mathrm{T}_{7}$ and which was found significantly $(\mathrm{P} \leq 0.05)$ superior than other treatments (Table 2). The higher uptake of nutrients under $\mathrm{T}_{7}$ which was might be due to higher application of nutrients along with FYM. Available nutrient status was also higher in $T_{6}$ and $T_{7}$ where FYM was applied. When we apply FYM in soil the entire amount of its NPK constituent was not made available at a time in one season; rather, a gradual release took place over a period of years. It has been reported that that only $25 \%$ to $30 \% \mathrm{~N}, 60 \%$ to $70 \% \mathrm{P}$, and $75 \% \mathrm{~K}$ could be made available from applied FYM in first season rice, and the remainder being available in subsequent years (Gaur et al., 1984). Hence, comparatively less yield deviation under integrated nutrient management was attributed to slow but sustained release of nutrients and due to improvement in humic substances in soil, which in turn promotes the soil NPK status.

\section{Conclusion}

The present study concluded that the application of $\mathrm{N}$, $\mathrm{P}$ and $\mathrm{K}$ based on STCR equation with $5 \mathrm{t} / \mathrm{ha}$ FYM achieved target yield of jute fibre $(\sim 3.5 \pm 0.2 \mathrm{t} / \mathrm{ha})$ and rice $(5 \mathrm{t} / \mathrm{ha})$ and recorded higher system productivity and benefit-cost ratio. It also maintained the soil fertility status of soil in jute-rice cropping system

\section{REFERENCES}

Balasubramanian, V.,Morales, A.C., Cruz, R.T. and Abdulrachman, S. (1999). On-farm adaptation of knowledge intensive nitrogen management technologies for rice systems. Nutrient Cycling in Agroecosystem, 53:59-69.

Balasubramanian, V., Ladha, J.K., Gupta, R.K ,Naresh, R.K.,Mehla, R.S.,. Singh, B.and Singh,Y.(2003). Technology options for rice in the rice-wheat system in South Asia. In: Improving the productivity and sustainability of rice-wheat systems: Issues and impacts. ASA special publication 65:135.

Gaur, A.C., Neelakantan, S. and Dargan.K.S.(1984). Organic manure. Indian Council of Agricultural Research, New Delhi, pp. 79-95.

Ghosh, A. (2008).Integrated nutrient management by using target yield equations for rice-jute system in eastern India. Journal of Sustainable Agriculture, 32:1, 149160.

Guha, B.,Das, K., Zaman, A.S.N. and Barman, B. (2008) Effect of integrated nutrient management on productivity of tossajute (Corchorus olitorius L.) and on soil properties. Madras Agricultural Journal, 95 (7-12) 359 -363.

Gomez, A.K., Gomez, A.A., 1984. Statistical Procedures for Agricultural Research, second ed. Wiley Inter Science, New York, $680 \mathrm{p}$.

Jackson, M.L.(1973). Soil Chemical Analysis. Prentice Hall of India Pvt. Ltd., New Delhi, 485 p.

Kumar, Neeraj, Srivastava, R.K., Singh, M.V., Singh, R.B. and Singh, R.K. (2010). Nitrogen substitution in jute (Corchorusolitorius) through green manure and farmyard manure for sustainable production in eastern tarai region of Uttar Pradesh(in) Jute and Allied Fibers Production, Utilization and Marketing.179-182. 
Ray, P.K., Jana, A.K., Moitra, D.N., Saha, M.N., Chaudhury, J. and Saha, A.R. (2000). Fertilizer prescription on soil test basis for jute, rice and wheat in typicustochrept. Journal of Indian Society of Soil Science, 48: 79-84.

Saha A.R., Mitra D.N., Mazumdar B., Saha S. and Mitra S. (2008). Effect on integrated nutrient management on roselle (Hibiscus sabdariffa) productivity its mineral nutrition and soil properties. Indian Journal of Agricultural Sciences, 78(5):418-421.
Singh M.V., Kumar, Neeraj and Singh, R.K.(2011). Influence of integrated nutrient management in mesta-rice crop sequence system in Eastern U.P. Annals of Plant and Soil Research, 13 (2):128-130.

Singh, S.R., Moitra, D.N., Majumdar, B., Tripathi, M.K., and Kundu, D.K. (2012). Soil test and target yield based nutrient management technology for higher productivity of jute. Jaf News, 10(1): pp.16. 